\title{
PENDIDIKAN KARAKTER PADA ANAK USIA DINI DALAM PERSPEKTIF ISLAM
}

\author{
M. Iksan Kahar
}

\begin{abstract}
The cultivation of character values in children is absolutely necessary with the aim of developing the child's basic potential so that he grows into a person who is goodhearted, well-thought and well-behaved. In essence, early childhood have different characteristics when compared to adults, early childhood have a high enough curiosity, like to play, imitate and imagine. It is through these characteristics that will be used as a foothold in instilling character values in these early childhood. Implementation of character education in schools in early childhood can be done through center-based learning that is beam centers, role playing centers, Qur'an centers, preparation centers and skills centers. The three centers are interrelated with one another which will make students have character in accordance with Islamic values.
\end{abstract}

Keywords: Education, character, early childhood

\section{PENDAHULUAN}

Pendidikan merupakan aset penting bagi kemajuan sebuah bangsa. Oleh karena itu, setiap warga negara harus dan wajib mengikuti jenjang pendidikan, baik jenjang pendidikan anak usia dini, pendidikan dasar, pendidikan menengah maupun perguruan tinggi. Kebanyakan anak-anak Indonesia dalam memulai proses masuk ke lembaga pendidikan, mengabaikan pendidikan anak usia dini, padahal untuk membiasakan diri dan mengembangkan pola pikir anak pendidikan sejak usia dini mutlak diperlukan.

Usia dini merupakan masa yang sangat penting dalam keseluruhan tahap perkembangan manusia. Pada masa itu terjadi lonjakan perkembangan anak yang tidak terulang pada periode berikutnya, sehingga ahli pendidikan anak usia dini menyebutnya sebagai usia emas perkembangan. Dalam Undang-Undang Perlindungan Anak, mengatakan bahwa anak mempunyai hak untuk tumbuh dan berkembang, bermain, beristirahat, berekreasi dan belajar dalam satuan pendidikan. 
124 | MUSAWA, Vol. 11 No. 1 Juni 2019 : 123 - 150

Orang tua dan pemerintah wajib menyediakan sarana dan prasarana pendidikan untuk anak dalam rangka program belajar. ${ }^{1}$ Dengan adanya Undang-Undang Perlindungan Anak tersebut, maka sangat penting adanya sebuah lembaga belajar khusus untuk belajar bagi anak-anak usia dini sebagai upaya pemenuhan sebagian dari hak anak.

Konstitusi negara Indonesia, PAUD telah memilki legalitas hukum yang tercantum dalam UU Sisdiknas No. 20 tahun 2003. Pasal 1, ayat 14 menyebutkan bahwa, Pendidikan Anak Usia Dini adalah suatu upaya pembinaan yang ditujukan kepada anak sejak lahir sampai dengan usia enam tahun yang dilakukan melalui pemberian rangsangan pendidikan untuk membantu pertumbuhan dan perkembangan jasmani dan rohani agar anak memiliki kesiapan dalam memasuki pendidikan lebih lanjut. ${ }^{2}$ Selanjutnya Pasal 28, ayat 3 menyebutkan bahwa pendidikan Anak Usia Dini pada jalur pendidikan formal berbentuk Taman Kanak-Kanak (TK), Raudathul Athfal, atau bentuk lain yang sederajat. ${ }^{3}$

Pendidikan Anak Usia Dini memegang peran dan pengaruh yang sangat besar dalam membangun dan mengembangkan karakter pada anak. Bahkan keberhasilan dan kesuksesan seseorang pada masa remaja dan tuanya juga sangat dipengaruhi oleh pendidikan yang dilalui di masa kecilnya. Oleh karena itu, orang tua harus benarbenar memberikan perhatian yang besar pada anak-anaknya semenjak usia dini.

Tujuan dari Pendidikan Anak Usia Dini itu sendiri antara lain Membentuk anak Indonesia yang berkualitas, yaitu anak yang tumbuh dan berkembang sesuai dengan tingkat perkembangannya, sehingga memiliki kesiapan yang optimal di dalam memasuki pendidikan dasar serta mengarungi kehidupan di masa dewasa. Selain itu,

${ }^{1}$ Republik Indonesia, Undang-Undang Perlindungan Anak (UU RI No. 23 Tahun 2002), (Jakarta: Sinar Grafika, 2009), h. 59-60.

${ }^{2}$ Undang-Undang, Undang-Undang RI Nomor 20 tahun 2003 tentang Sistem Pendidikan Nasional, (Bandung: Citra Umbara, 2006), h. 2.

${ }^{3}$ Ibid., h. 9. 
Pendidikan Anak Usia Dini juga bertujuan membantu menyiapkan anak mencapai kesiapan belajar (akademik) di sekolah. ${ }^{4}$

Pentingnya pendidikan bagi anak-anak yang direalisasikan dengan diadakannya program pemerintah berupa Pendidikan Anak Usia Dini adalah sebagai tempat bagi anak-anak dalam mengembangkan bakat dan kreatifitas mereka, karena masa anakanak merupakan masa di mana individu pertama-tama memperoleh pengetahuan dari lingkungan sekitarnya. Dalam pengetahuan yang diperolehnya, anak hanya sekedar mengadopsi tanpa melakukan sebuah evaluasi baik atau buruk pengetahuan yang diperolehnya. Semua pengetahuan akan diserap secara menyeluruh oleh anak-anak, tanpa adanya sikap penyaringan terhadap sesuatu yang baik atau buruk. Maka, lingkungan yang baik akan dapat membentuk karakter anak yang baik, sebaliknya lingkungan yang buruk juga akan dapat membentuk karakter anak yang buruk pula.

Pakar pendidikan, Arif Rahman sebagaimana dikutip oleh Ulil Amri Syafri menilai bahwa sampai saat ini masih ada yang keliru dalam pendidikan di Tanah Air. Menurutnya, titik berat pendidikan masih lebih banyak pada masalah kognitif. Penentu kelulusan pun masih lebih banyak pada prestasi akademik dan kurang memperhitungkan akhlak dan budi pekerti anak didik. ${ }^{5}$ Belum lagi jika diikuti statistik perkembangan kasus akhlak buruk anak didik. Misalnya; tawuran antara pelajar dan mahasiswa, plagiat dalam karya ilmiah, juga masalah pergaulan bebas yang sudah sangat meresahkan dan membosankan untuk didengar beritanya. ${ }^{6}$

Diakui atau tidak, saat ini terjadi krisis moral yang nyata dan mengkhawatirkan dalam masyarakat dan melibatkan harta yang paling berharga, yaitu anak-anak. Krisis itu antara lain berupa meningkatnya pergaulan bebas, bahkan seks bebas, maraknya angka kekerasan antar anak-anak dan juga remaja, kejahatan terhadap teman, penyalahgunaan obat-obatan, pornografi, perkosaan, perampasan dan pengrusakan

\footnotetext{
${ }^{4}$ Maimunah Hasan, PAUD (Pendidikan Anak Usia Dini), (Yogyakarta: DIVA Press, 2010), h. 16-17.

${ }^{5}$ Ulil Amri Syafri, Pendidikan Karakter Berbasis Al-Qur'an, (Cet. I; Jakarta: PT. Raja Grafindo Persada, 2012), h. 2.

${ }^{6} \mathrm{Ibid}$.
} 
126 | MUSAWA, Vol. 11 No. 1 Juni 2019 : 123 - 150

milik orang lain sudah menjadi masalah sosial yang hingga saat ini belum dapat diatasi secara tuntas. Perilaku remaja juga diwarnai dengan gemar menyontek, tawuran antar pelajar makin merebak. Begitu pula perilaku orang dewasa, seperti senang dengan konflik dan kekerasan, tindakan main hakim sendiri, perselingkuhan, bahkan perilaku korupsi di kalangan pejabat semakin merajalela. Dengan adanya beragam fenomena yang semakin krisis tentang karakter individu saat ini, maka penting untuk diadakan sebuah upaya dalam menumbuhkan karakter pada anak sedini mungkin.

\section{PEMBAHASAN}

\section{Pengertian dan Tujuan Pendidikan Karakter}

Sebelum diuraikan lebih lanjut tentang pengertian pendidikan karakter akan terlebih dahulu menguraikan tentang pengertian pendidikan, baru kemudian menguraikan pengertian karakter, sebab pendidikan karakter merupakan kalimat yang terdiri dari dua kata yaitu pendidikan dan karakter.

Pendidikan adalah usaha sadar terencana untuk mewujudkan suasana belajar dan proses pembelajaran agar anak didik secara aktif mengembangkan potensi dirinya untuk memiliki kekuatan spiritual keagamaan, pengendalian diri, kepribadian, kecerdasan, akhlak mulia, serta keterampilan yang diperlukan dirinya, masyarakat, bangsa dan negara. ${ }^{7}$ Dalam pengertian yang sederhana dan umum makna pendidikan sebagai usaha manusia untuk menumbuhkan dan mengembangkan potensi-potensi pembawaan baik jasmani maupun rohani sesuai dengan nilai-nilai dan norma-norma yang ada dalam masyarakat. ${ }^{8}$

Jadi, dapat dipahami bahwa pendidikan pada intinya ialah suatu bentuk pembimbingan dan pengembangan potensi peserta didik supaya terarah dengan baik dan mampu tertanam menjadi kepribadiannya dalam kehidupan sehari-hari.

${ }^{7}$ Undang-Undang RI Nomor 20 Tahun 2003, Tentang Sistem Pendidikan Nasional, (Bandung : Citra Umbara, 2009), h. 2.

${ }^{8}$ Fuad Ihsan, Dasar-Dasar Kependidikan, (Jakarta: Rineka Cipta, 2008), h. 2. 
Bentuk bimbingan dan pengembangan tersebut dilakukan secara sadar, terencana, dan sistematis oleh orang dewasa (pendidik) kepada anak-anak (anak didik) guna mencapai tujuan pendidikan yang ditetapkan. ${ }^{9}$

Berdasarkan pendapat tersebut pendidikan ialah proses internalisasi kultur, nilai-nilai agama serta norma ke dalam individu dalam rangka pengaktualisasian potensi yang ada di dalam dirinnya sehingga menjadi manusia yang beradab. Pendidikan bukan sarana transfer ilmu pegetahuan saja, namun sebagai sarana proses pengkulturan dan penyaluran nilai (enkulturisasi dan sosialisasi).

Berbicara tentang karakter, maka ada baiknya untuk mengetahui terlebih dahulu definisinya, agar difahami tentang pentingnya pengembangan karakter pada anak. Karakter berasal dari bahasa latin "charassein", "kharax", dalam bahasa inggris "character", Yunani "charactere dari kata "charassein" yang artinya mengukir, membuat tajam, atau membuat dalam", dan dalam bahasa Indonesia "Karakter". Dalam Kamus Poerwadarminta, karakter diartikan sebagai tabiat, watak, sifat-sifat kejiwaan, akhlak atau budi pekerti yang membedakan seseorang dengan yang lain. ${ }^{10}$ Adapun makna berkarakter adalah berkepribadian, berperilaku, bersifat, bertabiat, dan berwatak. Jadi, dapat dikatakan bahwa individu yang berkarakter baik adalah seseorang yang berusaha melakukan hal-hal yang terbaik terhadap Allah Swt. ${ }^{11}$

Sedangkan, Imam al-Ghazali berpendapat bahwa karakter lebih dekat dengan akhlak, yaitu spontanitas manusia dalam bersikap atau perbuatan yang telah menyatu dalam diri manusia sehingga ketika muncul tanpa perlu dipikirkan atau direncanakan sebelumnya. ${ }^{12}$ Dalam pandangan Islam, akhlak adalah sifat yang berada dalam jiwa

\footnotetext{
${ }^{9}$ Muhammad Fadlillah \&Lilif Mualifatu Khorida, Pendidikan Karakter Anak Usia Dini,(Jogjakarta: Ar-Ruzz Media, 2013), h. 19

${ }^{10}$ Abdul Majid, Dian Andayani, Pendidikan Karakter Perspektif Islam, (Bandung: PT. Remaja Rosdakarya, 2012), h. 11.

${ }^{11}$ Ulil Amri Syafri, Pendidikan Karakter Berbasis Al-Qur"an, (Jakarta: Rajawali Pers, 2014), h. 7

${ }^{12}$ Al-Ghazali, Mengobati Penyakit Hati Membentuk Akhlak Mulia, (Bandung: Kharisma,1994), h. 31 .
} 
128 | MUSAWA, Vol. 11 No. 1 Juni 2019: 123 - 150

yang mendorong seseorang untuk melakukan perbuatan secara tidak sadar dan tanpa melalui pemikiran dan pertimbangan terlebih dahulu.

Munir juga berpendapat bahwa definisi karakter sebagai sebuah pola, baik itu pikiran, sikap, maupun tindakan yang melekat pada diri seseorang dengan sangat kuat dan sulit dihilangkan. ${ }^{13}$ Sedangkan menurut Hermowo, karakter adalah watak, sifat atau hal-hal yang memang sangat mendasar yang ada pada diri seseorang. Selanjutnya, Hermowo juga memberikan makna karakter sebagai tabiat dan akhlak atau budi pekerti yang membedakan seseorang dengan yang lain. ${ }^{14}$

Dilihat dari beberapa pengertian tersebut, bahwa karakter dan akhlak tidak terdapat perbedaan yang signifikan. Karakter dan akhlak sama-sama menunjukkan sebuah perbuatan yang lahir secara spontan tanpa olahan pikiran untuk memikirkan untung dan rugi, dengan kata lain dapat disebut dengan kebiasaan.

Dengan demikian, pendidikan karakter adalah usaha yang sungguh-sungguh untuk memahami, membentuk, memupuk nilai-nilai etika, baik untuk diri sendiri maupun untuk semua warga negara secara keseluruhan. Pendidikan karakter juga dapat dikatakan sebagai pendidikan untuk "membentuk" kepribadian seseorang melalui pendidikan budi pekerti, yang hasilnya terlihat dalam tindakan nyata seseorang, yaitu tingkah laku yang baik, jujur, bertanggung jawab, menghormati hak orang lain, kerja keras dan sebagainya.

Menurut sejarah diungkapkan bahwa pendidikan karakter merupakan misi utama Nabi Muhammad saw dalam menyebarkan agama Islam. Dalam Islam disebutkan Nabi Muhammad memiliki akhlak yang agung. Allah Swt, berfirman dalam (Q.S Al-Qalam, [68]: 4), yaitu:

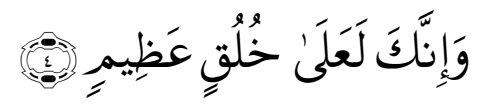

\footnotetext{
${ }^{13}$ Abdullah Munir, Pendidikan Karakter, (Yogyakarta: Pedagogia, 2010), h. 3.

${ }^{14}$ Hermowo, Self Digesting : Alat Menjelajahi dan Mengurai diri, (Bandung: Mizan Media Utama, 2004), h. 175
} 
Terjemahnya:

Dan Sesungguhnya engkau benar-benar berbudi pekerti yang luhur' (Q.S AlQalam, [68]: 4). ${ }^{15}$

Akhlak terpuji dicontohkan nabi diantaranya, menjaga amanah, dapat dipercaya, bersosialisasi dan berkomunikasi efektif dengan umat manusia sesuai harkat dan martabatnya, membantu sesama manusia dalam kebaikan, memuliakan tamu, menghindari pertengkaran, memahami nilai dan norma yang berlaku, serta bermusyawarah dalam segala urusan untuk kepentingan bersama.

Nabi Muhammad SAW sejak awal tugasnya mempunyai suatu pernyataan bahwa dirinya diutus untuk menyempurnakan akhlak (karakter). Beliau bersabda:

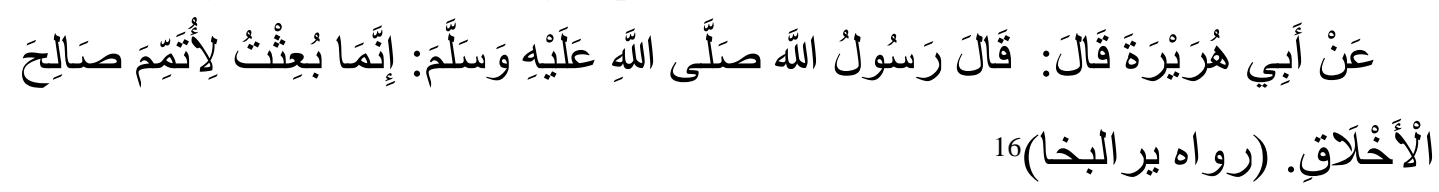

Artinya:

Dari Abu Hurairah ra. berkata bahwa Rasulullah Saw pernah bersabda: Sesungguhnya Aku ini diutus ke dunia ialah untuk menyempurnakan akhlak yang mulia. (H.R. Bukhori).

Sabda Rasulullah tersebut diatas menunjukkan tiada lain bahwa kehidupan manusia ini semestinya bersandar pada segala perilaku positif dan tindakan terpuji. Itulah semua bagian dari sebuah akhlak yang mulia.

Selain definisi diatas, terdapat tujuan dari penidikan karakter itu sendiri. Ahmad Tafsir mengemukakan bahwa tujuan pendidikan secara umum adalah untuk memanusiakan manusia. ${ }^{17}$ Sedangkan tujuan dari pendidikan karakter atau akhlak adalah agar manusia menjadi baik dan terbiasa kepada yang baik tersebut. Dengan

\footnotetext{
${ }^{15}$ Departemenen Agama Republik Indonesia, Al-Qur'an dan terjemahnya (Surabaya: Duta Ilmu, 2002)h. 826

${ }^{16}$ Al-Bukhori, Shohihul Bukhori, Jilid II (Singapura: Sulaman Mar'i, t.th), h. 273.

${ }^{17}$ Ahmad Tafsir, Pendidikan Agama Islam, (Bandung: Maestro, 2008), h. 29.
} 
130 | MUSAWA, Vol. 11 No. 1 Juni 2019: 123 - 150

demikian, dapat dikatakan bahwa tujuan pendidikan dan latihan yang dapat melahirkan tingkah laku sebagai sesuatu tabiat ialah agar perbuatan yang timbul dari akhlak baik tadi dirasakan sebagai suatu kenikmatan bagi yang melakukannya.

Tujuan dari pendidikan karakter dalam perspektif Islam adalah pertama, supaya seseorang terbiasa melakukan perbuatan baik. Kedua, supaya interaksi manusia dengan Allah SWT dan sesama makhluk lainnya senantiasa terpelihara dengan baik dan harmonis. Esensinya sudah tentu untuk memperoleh yang baik, seseorang harus membandingkannya dengan yang buruk atau membedakan keduanya. Kemudian setelah itu, dapat mengambil kesimpulan dan memilih yang baik tersebut dengan meninggalkan yang buruk. Dengan karakter yang baik maka kita akan disegani orang. Sebaliknya, seseorang dianggap tidak ada, meskipun masih hidup, kalau akhlak atau karakternya rusak. ${ }^{18}$

Berdasarkan hal tersebut dapat disimpulkan bahwa tujuan pendidikan karakter, yaitu mengembangkan potensi dasar anak agar ia tumbuh menjadi sosok yang berhati baik, berpikiran baik, dan berperilaku baik.

\section{Konsep Pendidikan Anak Usia Dini}

Sebelum dibicarakan tentang pendidikannya terlebih dahulu akan dibahas tentang anak usia dini. Adapun yang dimaksud anak usia dini adalah kelompok manusia yang berusia 0-6 tahun. Menurut pakar pendidikan anak, yaitu kelompok manusia yang berusia 0-8 tahun. Jadi anak usia dini adalah kelompok anak yang berada dalam proses pertumbuhan dan perkembangan yang bersifat unik, dalam arti memiliki pola pertumbuhan dan perkembangan (koordinasi motorik halus dan kasar), intelegensi (daya pikir, daya cipta, kecerdasan emosi, dan kecerdasan spiritual), sosial emosional (sikap dan prilaku serta agama), bahasa dan komunikasi yang khusus sesuai dengan tingkat pertumbuhan dan perkembangan anak. ${ }^{19}$

\footnotetext{
${ }^{18}$ Saifuddin Aman, 8 Pesan Lukman Al-Hakim, (Jakarta: Almawardi Prima, 2008), h. 25.

${ }^{19}$ Depdiknas, Kurikulum Hasil Belajar Pendidikan Anak Usia Dini, (Jakarta: Depdiknas, 2002),
} h. 3-4. 
Soemiarti menyebutkan bahwa anak usia dini disebut pula sebagai anak prasekolah, yang di Indonesia biasanya mengikuti program di tempat penitipan anak, B Teach (Baby Teach) dan taman kanak-kanak. ${ }^{20}$ Berdasarkan keunikan dalam pertumbuhan dan perkembangannya, anak usia dini terbagi dalam empat tahapan, yaitu:

a. Masa bayi lahir sampai 12 bulan

b. Masa balita usia 1-3 tahun,

c. Masa prasekolah usia 3-6 tahun

d. Masa kelas awal SD 6-8 tahun.

Setelah diketahui pengertian anak usia dini, berikut dipaparkan tentang Pendidikan Anak Usia Dini (PAUD). PAUD adalah suatu proses pembinaan tumbuh kembang anak usia lahir hingga enam tahun secara menyeluruh, yang mencakup aspek fisik maupun non fisik dengan memberikan rangsangan bagi perkembangan jasmani, rohani (moral dan spiritual), motorik, akal pikir, emosional dan sosial yang tepat agar anak dapat tumbuh dan berkembang secara optimal.

Adapun upaya yang dilakukan mencakup stimulasi intelektual, pemeliharaan kesehatan, pemberian nutrisi, dan penyediaan kesempatan yang luas untuk mengeksplorasi dan belajar secara aktif.

Dalam firman Allah Swt (Q.S. Ar-Ruum, [30]: 30), yaitu:

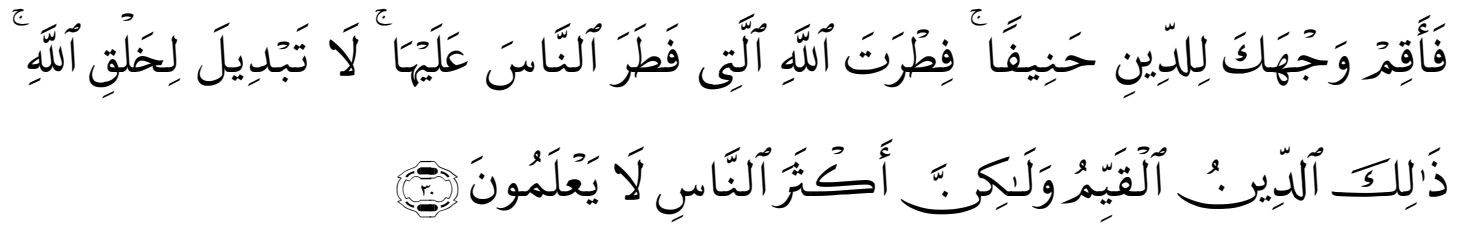

Terjemahnya:

Maka hadapkanlah wajahmu dengan lurus kepada agama Allah; (tetaplah atas) fitrah Allah yang Telah menciptakan manusia menurut fitrah itu. tidak ada perubahan

\footnotetext{
${ }^{20}$ Soemarti Patmonodewo, Pendidikan anak Pra Sekolah (Jakarta: PT Asdi Mahastya, 2003)h.
} 19 
132 | MUSAWA, Vol. 11 No. 1 Juni 2019 : 123 - 150

pada fitrah Allah. (Itulah) agama yang lurus; tetapi kebanyakan manusia tidak mengetahui' (Q.S. Ar-Ruum, [30]: 30). ${ }^{21}$

Pendidikan usia dini dalam perspektif pendidikan Islam adalah usaha membantu anak agar fitrah yang disebut dengan kecakapan/ability, baik fisik maupun non fisik itu dapat dibantu perkembangannya sejak dini. Pendidikan usia dini dapat dimaknai sebagai semua proses yang mengarah pada bantuan pemeliharaan jiwa manusia untuk selalu berada dalam kemaslahatan hidup baik di dunia maupun di akhirat, dan membantu agar fitrah yang merupakan kecakapan potensial yang dibawa sejak kelahirannya dapat berkembang secara maksimal sesuai dengan ketentuan dalam syari'at Islam. ${ }^{22}$

Pendidikan anak usia dini mempunyai bermacam-macam tujuan, yaitu:

a. Tujuan Umum, Dalam buku garis-garis besar program kegiatan belajar pendidikan anak usia dini dijelaskan bahwa: "Pendidikan anak usia dini bertujuan untuk membantu meletakkan dasar kearah perkembangan sikap, pengetahuan, keterampilan, dan daya cipta yang diperlukan anak didik dalam menyesuaikan diri dengan lingkungannya dan untuk pertumbuhan serta pengembangan kemampuan bermasyarakat, serta pengembangan dasar melalui kegiatan yang dipersiapkan oleh guru meliputi pengembangan kemampuan berbahasa, daya pikir, daya cipta, keterampilan dan jasmani. ${ }^{23}$

Tujuan Pendidikan anak usia dini adalah membentuk manusia sejati, yang bertakwa kepada Tuhan Yang Maha Esa, yang cakap, sehat, terampil, serta bertanggung jawab terhadap masyarakat, bangsa, dan negara.

b. Tujuan Khusus, Adapun tujuan khusus dari pendidikan anak usia dini adalah Pertama, memberikan kesempatan kepada anak untuk memenuhi kebutuhan kebutuhan fisik maupun psikologinya dan mengembangkan potensi-potensi yang

\footnotetext{
${ }^{21}$ Departemenen Agama Republik Indonesia, Al-Qur'an h. 574.

${ }^{22}$ Nana Syaodih Sukmadinata, Landasan Psikologi Proses Pendidikan, (Cet.II; Bandung: Remaja Rosdakarya, 2004), h. 92.

${ }^{23}$ Moeslichatoen R, Metode Pengajaran di Taman Kanak-Kanak, (Cet. I; Jakarta: Rosda Karya, 2007), h. 3.
} 
ada padanya secara optimal sebagai individu yang unik. Kedua, memberikan bimbingan yang seksama agar anak memiliki sifat dan kebiasaan yang baik. Ketiga, mencapai kematangan mental dan fisik yang dibutuhkan agar dapat melanjutkan pada jenjang yang lebih tinggi. ${ }^{24}$

Jadi, diantara tujuan pendidikan anak usia dini adalah untuk menyiapkan fisik dan psikologisnya untuk menghadapi pendidikan sekolah dasar. Dengan cara membantu anak mengekspresikan dirinya dan memberikan kesempatan untuk melatih kreatifitas, daya cipta dan imajinasinya, sehingga anak mempunyai kepercayaan diri untuk melangkah ke depan.

Pendidikan dalam pandangan Islam dimaksudkan untuk peningkatan potensi spiritual dan membentuk anak agar menjadi manusia yang beriman dan bertakwa kepada Tuhan Yang Maha Esa dan berakhlak mulia. Akhlak mulia mencakup etika, budi pekerti, dan moral sebagai perwujudan dari tujuan pendidikan. Tujuan pendidikan Islam tidak hanya membentuk anak yang beriman, berakhlak mulia, beramal shaleh tetapi juga menjadikan anak tersebut berilmu pengetahuan dan berteknologi, juga berketerampilan dan berpengalaman sehingga ia menjadi orang yang mandiri berguna bagi dirinya, agama, orang tua serta negaranya. ${ }^{25}$

Berdasarkan uraian di atas, dapat disimpulkan bahwa tujuan pendidikan menurut Islam adalah membentuk seorang muslim yang mampu melaksanakan kewajibannya kepada Allah, sebagaimana firman Allah Swt dalam (Q.S. AdzDzariyaat, [51]: 56), yaitu:

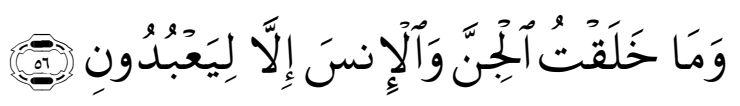

Terjemahnya:

Dan Aku tidak menciptakan jin dan manusia melainkan supaya mereka beribadah kepada-Ku' (Q.S. Adz-Dzariyaat, [51]: 56). ${ }^{26}$

\footnotetext{
${ }^{24}$ Soemiarti Patmonodewo, Pendidikan Anak Prasekolah, (Jakarta: Rineka Cipta, 2000), h. 59.

${ }^{25}$ Abuddin Nata, Kapita Selekta Pendidikan Islam, (Jakarta: PT. Raja Grafindo Persada, 2012),

${ }^{26}$ Departemenen Agama Republik Indonesia, Al-Qur'an h. 756.
} h. 140. 
134 | MUSAWA, Vol. 11 No. 1 Juni 2019 : 123 - 150

Maksud dari kata menyembah di ayat ini adalah mentauhidkan Allah dalam segala macam bentuk ibadah. Tujuan pendidikan dalam Islam harus terkait dengan tujuan penciptaan manusia itu sendiri di dunia ini, yakni menyembah Allah SWT dengan segala aspeknya ibadahnya, baik yang berhubungan dengan Allah, sesama manusia maupun dengan lingkungannya. Ibadah yang juga berhubungan dengan masalah ukhrowi (akhirat) maupun masalah duniawi (dunia).

\section{Pendidikan Karakter menurut Al-Qur'an}

Islam memandang penting karakter dalam Pendidikan, seperti yang telah di bahas sebelumnya bahwa misi utama nabi Muhammad saw yakni memperbaiki akhlak yang merupakan sebutan karakter dalam Islam. Bahkan nabi-nabi sebelumnya telah memberikan contoh nilai-nilai yang baik dalam berakhlak. Firman Allah Swt dalam Al-Qur'an surah Luqman (31) ayat 13-19:

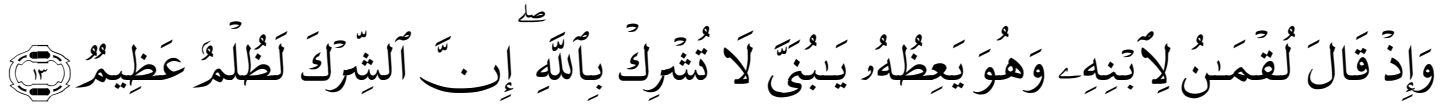

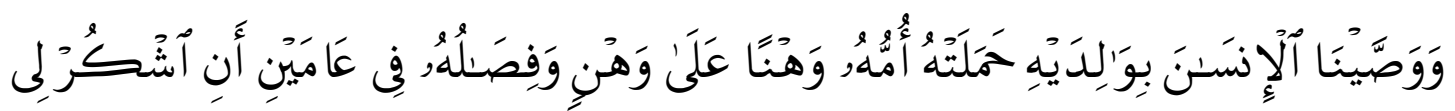

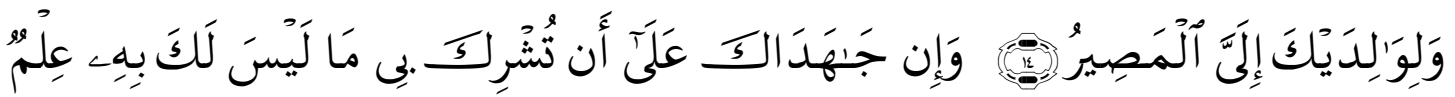

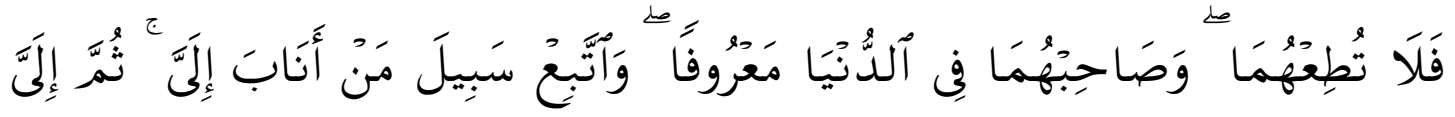

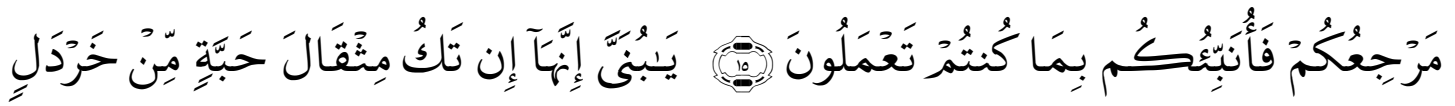

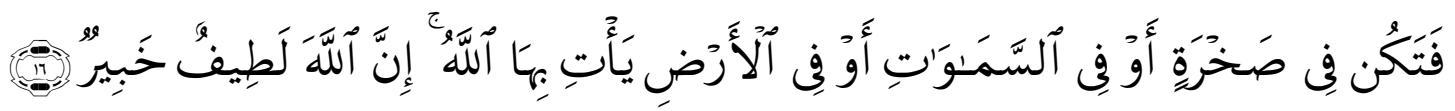

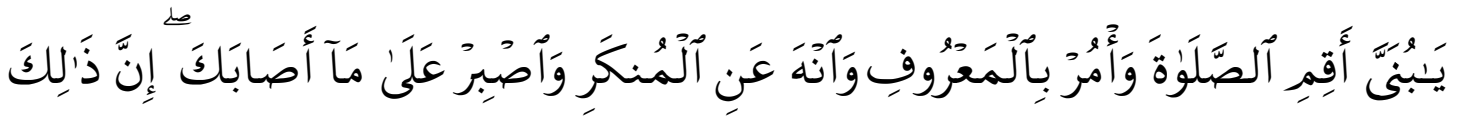

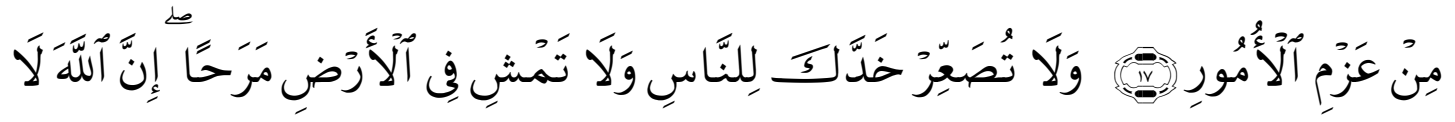




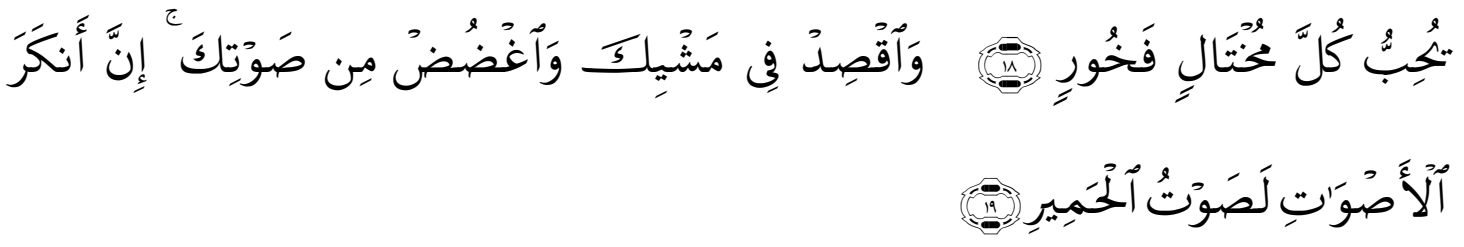

Terjemahnya:

(13) dan (ingatlah) ketika Luqman berkata kepada anaknya, di waktu ia memberi pelajaran kepadanya: "Hai anakku, janganlah kamu mempersekutukan Allah, Sesungguhnya mempersekutukan (Allah) adalah benar-benar kezaliman yang besar".

(14) dan Kami perintahkan kepada manusia (berbuat baik) kepada dua orang ibubapanya; ibunya telah mengandungnya dalam Keadaan lemah yang bertambahtambah, dan menyapihnya dalam dua tahun. bersyukurlah kepadaku dan kepada dua orang ibu bapakmu, hanya kepada-Kulah kembalimu.

(15) dan jika keduanya memaksamu untuk mempersekutukan dengan aku sesuatu yang tidak ada pengetahuanmu tentang itu, Maka janganlah kamu mengikuti keduanya, dan pergaulilah keduanya di dunia dengan baik, dan ikutilah jalan orang yang kembali kepada-Ku, kemudian hanya kepada-Kulah kembalimu, Maka Kuberitakan kepadamu apa yang telah kamu kerjakan.

(16)(Luqman berkata): "Hai anakku, Sesungguhnya jika ada (sesuatu perbuatan) seberat biji sawi, dan berada dalam batu atau di langit atau di dalam bumi, niscaya Allah akan mendatangkannya (membalasinya). Sesungguhnya Allah Maha Halus[1181] lagi Maha mengetahui.

(17) Hai anakku, dirikanlah shalat dan suruhlah (manusia) mengerjakan yang baik dan cegahlah (mereka) dari perbuatan yang mungkar dan bersabarlah terhadap apa yang menimpa kamu. Sesungguhnya yang demikian itu Termasuk hal-hal yang diwajibkan (oleh Allah).

(18) dan janganlah kamu memalingkan mukamu dari manusia (karena sombong) dan janganlah kamu berjalan di muka bumi dengan angkuh. Sesungguhnya Allah tidak menyukai orang-orang yang sombong lagi membanggakan diri. 
136 | MUSAWA, Vol. 11 No. 1 Juni 2019 : 123 - 150

(19) dan sederhanalah kamu dalam berjalan dan lunakkanlah suaramu. Sesungguhnya seburuk-buruk suara ialah suara keledai. ${ }^{27}$

Ayat tersebut di atas, menguraikan tentang salah seorang yang bernama Luqman yang di anugerahkan oleh Allah Swt berupa hikmah, sambil menjelaskan beberapa hikmah yang pernah beliau sampaikan kepada anaknya sekaligus sebagai wujud penanaman nilai-nilai karakter yaitu:

a. Karakter keimanan yakni Luqman memulai nasehatnya dengan menekankan perlunya menghindari syirik/mempersekutukan Allah.

b. Karakter Berbuat baik kepada ke dua orang tua. ${ }^{28}$

Berbuat baik kepada ke dua orang hukumnya wajib dan durhaka kepada ke duanya hukumnya haram. Sebab tidak ada yang mengingkari keutamaan orang tua selain orang yang tercela. ${ }^{29}$

c. Karakter Bertanggung Jawab 132-140

d. Karakter Jujur

e. Karakter Sabar dan Tabah

f. Karakter Santun dan tidak Sombong. ${ }^{30}$

Selain ayat tersebut, berbagai karakter yang harus dimiliki antara lain:

1) Berbuat adil, tolong menolong, saling mengasihi, dan saling menyayangi. ${ }^{31}$ Seperti yang tercantum dalam Al-Qur'an surat An-nahl(16) ayat 90.

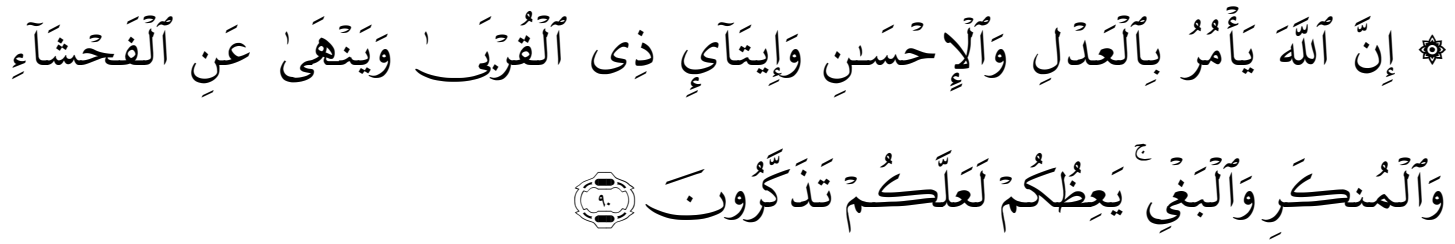

\footnotetext{
${ }^{27}$ Departemenen Agama Republik Indonesia, Al-Qur'an, h. 587-588

${ }^{28}$ M. Quraish Shihab, Tafsir Al-misbah, Pesan, Kesan dan Keserasian Al-Qur'an, (Jakarta: Lentera Hati, 2002), h. 123-130

${ }^{29}$ Ibrahim Abdul Muqtadir, Wisdom Of Luqman El-hakim: 12 cara membentengi Kerusakan Akhlak, (Solo:Aqwam, 2008), h. 63

${ }^{30}$ M. Quraish Shihab, Tafsir, h. 132-140

${ }^{31}$ Muchlas Samani dan Hariyanto, Konsep dan Model Pendidikan Karakter, (Bandung: PT Remaja Rosdakarya, 2012) h. 79
} 
Terjemahnya:

Sesungguhnya Allah menyuruh (kamu) Berlaku adil dan berbuat kebajikan, memberi kepada kaum kerabat, dan Allah melarang dari perbuatan keji, kemungkaran dan permusuhan. Dia memberi pengajaran kepadamu agar kamu dapat mengambil pelajaran. ${ }^{32}$

2) Teguh hati dan tidak berutus asa, seperti yang tercantum dalam surah Yusuf(12):87.

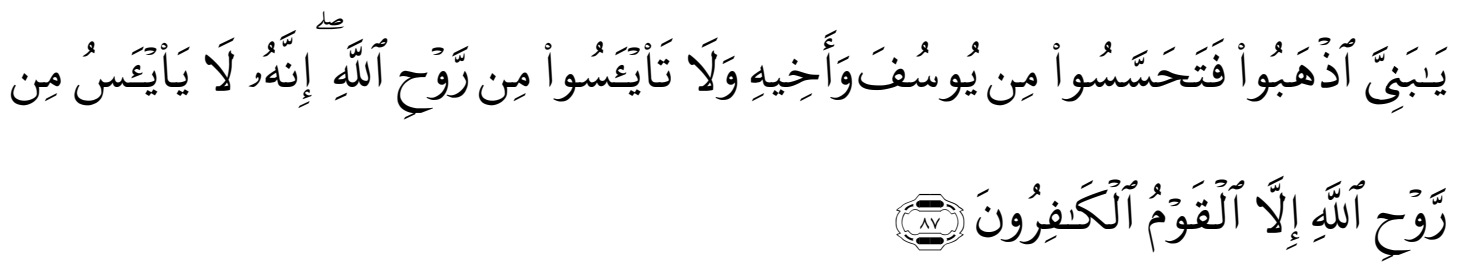

Terjemahnya:

Hai anak-anakku, Pergilah kamu, Maka carilah berita tentang Yusuf dan saudaranya dan jangan kamu berputus asa dari rahmat Allah. Sesungguhnya tiada berputus asa dari rahmat Allah, melainkan kaum yang kafir". ${ }^{33}$

3) Bertanggung Jawab ${ }^{34}$, seperti yang tercantum dalam Al-Qur'an surah AlQiyamah(75):36.

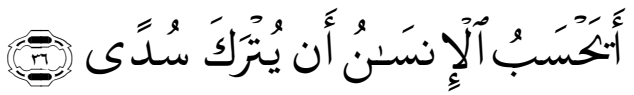

Terjemahnya:

Apakah manusia mengira, bahwa ia akan dibiarkan begitu saja (tanpa pertanggung jawaban)?. ${ }^{35}$

Berdasarkan ayat tersebut di atas, berbagai macam karakter yang harus dikembangkan dalam diri anak didik dalam ranah pendidikan mencakup di antaranya Berbuat adil, tolong menolong, saling mengasihi, dan saling menyayangi, Teguh

\footnotetext{
${ }^{32}$ Departemenen Agama Republik Indonesia, Al-Qur'an, h. 377

${ }^{33}$ Ibid., h. 311

${ }^{34}$ Muchlas Samani dan Hariyanto, Konsep, h. 85

${ }^{35}$ Departemenen Agama Republik Indonesia, Al-Qur'an, h. 855
} 
138 | MUSAWA, Vol. 11 No. 1 Juni 2019 : 123 - 150

hati dan tidak berutus asa dan bertanggung jawab. Tentunya dalam hal ini belum menjadi hal mutlak sebab masih banyak lagi karakter-karakter positif yang dapat di ajarkan kepada anak.

Ryan dan Bohlin mengatakan bahwa, karakter mengandung tiga unsur pokok, yaitu mengetahui kebaikan, mencintai kebaikan dan melakukan kebaikan. Dalam pendidikan karalter kebaikan itu sering kali di rangkum dalam sederet sifat-sifat baik. Dengan demikian, maka pendidikan karakter sebuah upaya membimbing kecakapan-kecakapan yang penting yang mencangkup perkembangan sosial anak didik. ${ }^{36}$ hal ini mengisyaratkan bahwa karakter baik harus ditanamkan kepada anak sedini mungkin mulai dari memperkenalkan hingga pelaksanaannya dalam wujud perilaku kebaikan anak didik dilingkungan sosialnya yang harus melalui bimbingan para pelaku pendidikan.

\section{Metode-metode Pendidikan Karakter}

Pendidikan karakter telah menjadi suatu pergerakan pendidikan yang mendukung pengembangan sosial, pengembangan emosional, dan pengembangan etika para anak didik. Merupakan suatu upaya proaktif yang dilakukan baik oleh sekolah maupun pemerintah untuk membantu anak didik mengembangkan inti pokok dari nilai-nilai etik dan nilai-nilai kinerja, seperti kepedulian, kejujuran, fairness, keuletan, dan ketabahan (fortitude),tanggung jawab, menghargai diri sendiri dan orang lain. ${ }^{37}$

Melaksanakan pendidikan karakter tidaklah semudah yang kita bayangkan. Lebih-lebih pada dunia pendidikan di sekolah. perlu adanya persiapan-persiapan, seperti perencanaan dan pelaksanaan pembelajaran, serta dibutuhkan pendidikpendidik yang berkompeten, professional, dan berkepribadian baik. ${ }^{38}$ Dalam dunia

\footnotetext{
${ }^{36}$ Abdul Majid dan Dian Andayani, Pendidikan Karakter Perspektif Islam(Bandung: PT Remaja Rosdakarya, 2012), h. 11

${ }^{37}$ Muchlas Samani dan Hariyanto, Konsep dan Model Pendidikan Karakter, (Bandung : $\quad$ PT Remaja Rosdakarya, 2012), h. 43

${ }^{38}$ Muhammad fadlillah \&Lilif Mualifatu Khorida, Pendidikan Karakter Anak Usia Dini, (Jogjakarta: Ar-Ruzz Media, 2013), h. 29
} 
pendidikan Islam, proses pendidikan karakter bukan hanya sekedar memberikan wawasan melalui pendekatan verbalis yang cenderung menghapal dan dijadikan sekedar wawasan. Namun, proses tersebut harus mampu mendorong anak untuk melakukan akhlak yang baik dan mampu mencegah mereka untuk melakukan akhlak tercela. Salah satunya adalah dengan menggunakan metode pendidikan yang digunakan dalam Al-Qur'an.

Metode berasal dari bahasa latin "meta" yang berarti melalui, dan "hodos" yang berarti jalan atau cara. Dalam bahasa Arab disebut "tariqah" artinya jalan, cara, sistem atau ketertiban dalam mengerjakan sesuatu. Sedangkan menurut istilah ialah suatu sistem atau cara yang mengatur suatu cita-cita. ${ }^{39}$ Dalam Kamus Besar Bahasa Indonesia, metode yaitu cara atau jalan yang digunakan untuk memudahkan pelaksanaan suatu kegiatan guna mencapai tujuan yang telah ditentukan. ${ }^{40}$

Berdasarkan hal tersebut, dapat dikatakan bahwa metode pendidikan karakter adalah cara yang digunakan untuk mencapai tujuan pendidikan dalam pembentukan karakter. Dengan adanya metode pendidikan karakter maka pendidikan karakter dapat dilaksanakan secara integral dan utuh, sehingga tujuan pendidikan karakter akan semakin terarah dan efektif. ${ }^{41}$

Metode yang digunakan untuk pendidikan anak harus dapat mengoptimalkan kemampuan anak. Proses pendidikan yang dilaksanakan juga harus disesuaikan dengan tingkat usia anak, dari mulai perkembangan anak awal sampai dewasa. Dalam proses pendidikan, kesalahan pendidikan anak usia dini akan berdampak negatif terhadap perkembangan anak di masa yang akan datang, untuk memperoleh kualifikasi metode yang tepat guna, pemilihan metode harus didasarkan pada karakteristik perkembangan anak yang sesuai dengan periodesasi anak itu.

\footnotetext{
${ }^{39}$ Nur Uhbiyati, Ilmu Pendidikan Islam, (Bandung: Pustaka Setia, 1989), h. 123.

${ }^{40}$ Tim Penyusun Kamus Pusat Pembinaan dan Pengembangan Bahasa, Kamus Besar Bahasa Indonesia, (Jakarta: Balai Pustaka, 1989), h. 581.

${ }^{41}$ Novan Ardy Wiyani, Manajemen Pendidikan Karakter : Konsep dan Implementasinya di Sekolah, (Yogyakarta: Pedagogia, 2012), h. 72.
} 
140 | MUSAWA, Vol. 11 No. 1 Juni 2019: 123 - 150

Jadi yang dimaksud metode adalah cara kerja yang bersistem dan digunakan untuk mencapai tujuan yang ditetapkan. Untuk mencapai tujuan pendidikan karakter, khususnya pendidikan yang mengutamakan karakter pribadi muslim maka diperlukan metode yang dapat mengantar kearah tujuan pendidikan Islam. Adapun metodemetode pendidikan karakter dalam Al-Qur'an, yaitu:

a. Metode Perintah

Perintah dalam Islam dikenal dengan sebutan al-amr. Al-amr diartikan sebagai permintaan untuk melaksanakan suatu pekerjaan. Beberapa contoh metode perintah yang terdapat pada Al-Qur'an antara lain:

1) Perintah untuk menjadikan sabar dan shalat sebagai penolong.

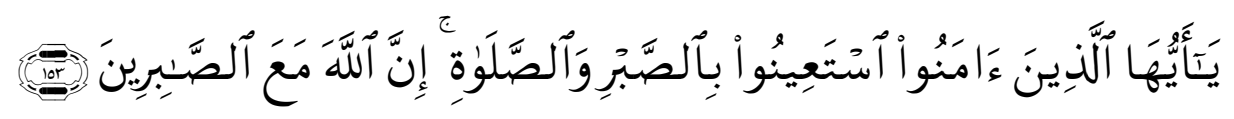

Terjemahnya:

Hai orang-orang yang beriman, jadikanlah sabar dan shalat sebagai penolongmu, Sesungguhnya Allah beserta orang-orang yang sabar'(Q.S. Al-Baqarah, [2]: 153). ${ }^{42}$

2) Perintah untuk bersuci ketika melaksanakan shalat.

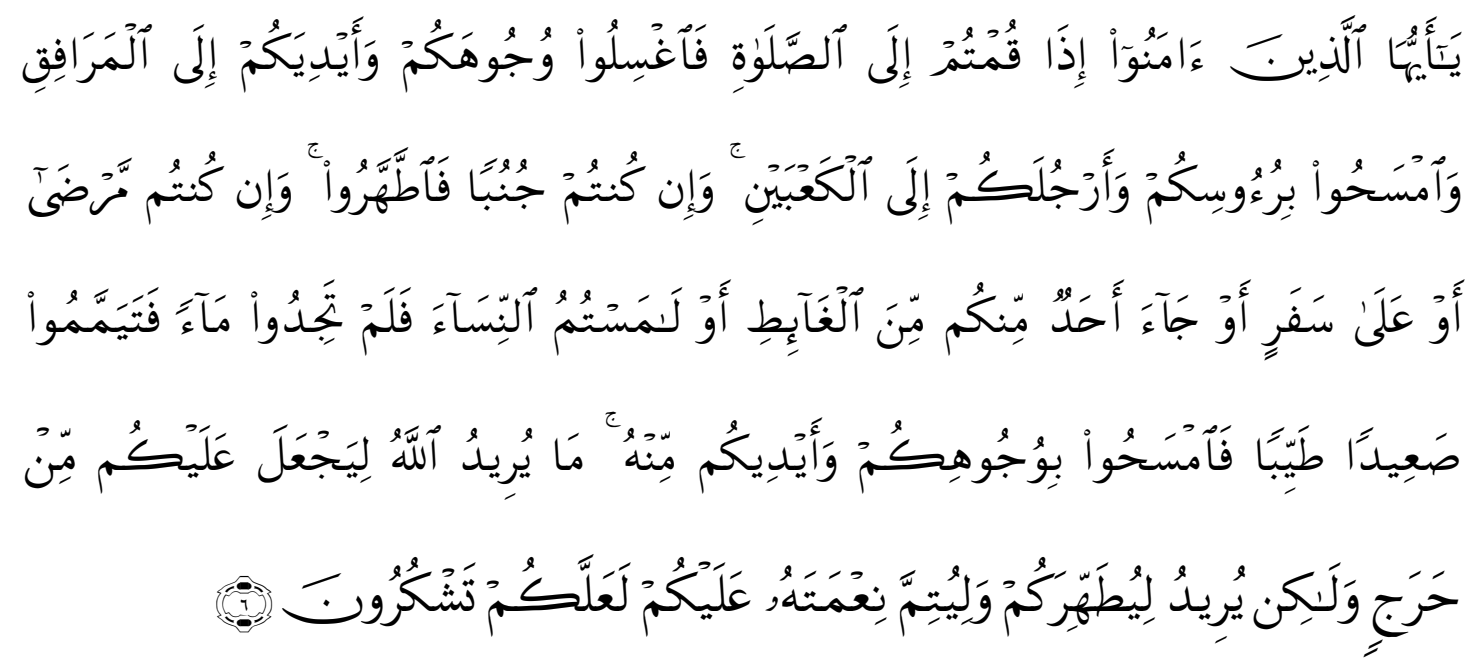

${ }^{42}$ Departemenen Agama Republik Indonesia, Al-Qur'an, h. 29 
Terjemahnya:

Hai orang-orang yang beriman, apabila kamu hendak mengerjakan shalat, Maka basuhlah mukamu dan tanganmu sampai dengan siku, dan sapulah kepalamu dan (basuh) kakimu sampai dengan kedua mata kaki, dan jika kamu junub Maka mandilah, dan jika kamu sakit atau dalam perjalanan atau kembali dari tempat buang air (kakus) atau menyentuh perempuan, lalu kamu tidak memperoleh air, Maka bertayammumlah dengan tanah yang baik (bersih); sapulah mukamu dan tanganmu dengan tanah itu. Allah tidak hendak menyulitkan kamu, tetapi dia hendak membersihkan kamu dan menyempurnakan nikmat-Nya bagimu, supaya kamu bersyukur' (Q.S. Al-Maa'idah, [5]: 6). ${ }^{43}$

Metode pendidikan karakter dalam Al-Qur'an amat banyak digunakan melalui kalimat-kalimat perintah. Metode ini mendidik manusia untuk melakukan suatu amalan yang ditetapkan ajaran agama. Bila dunia pendidikan menyebutkan bahwa tujuan pendidikan adalah perubahan-perubahan yang diinginkan kepada taraf lebih baik, maka metode perintah yang terdapat dalam Al-Qur'an mengarahkan sikap dan perilaku anak didik ke arah tersebut.

b. Metode Larangan

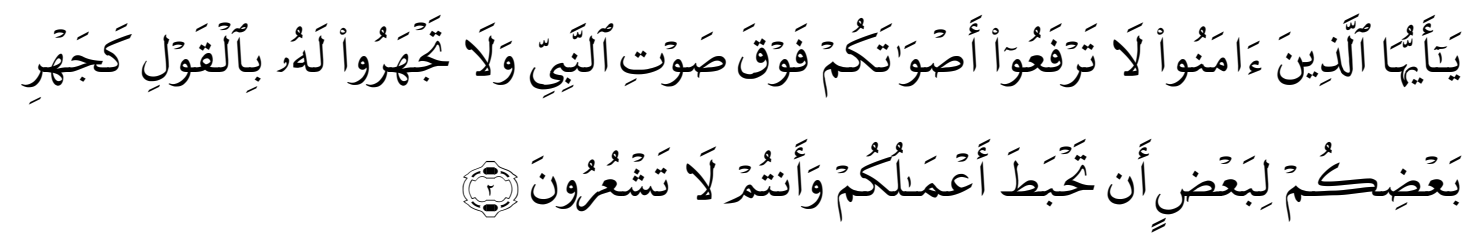

Terjemahnya:

Hai orang-orang yang beriman, janganlah kamu meninggikan suaramu melebihi suara nabi, dan janganlah kamu Berkata kepadanya dengan suara yang keras, sebagaimana kerasnya suara sebagian kamu terhadap sebagian yang lain, supaya tidak hapus (pahala) amalanmu, sedangkan kamu tidak menyadari' (Q.S. AlHujuraat [49]: 2). ${ }^{44}$ 
142 | MUSAWA, Vol. 11 No. 1 Juni 2019 : 123 - 150

Larangan dalam kajian Islam memiliki cakupan pengertian yang luas bila ditinjau dari aspek waktu, yaitu ada yang mutlaq (tak terbatas) dan muqayyad (terbatas). Metode larangan adalah bentuk pembatasan, artinya dunia pendidikan Islam harus memiliki pembatasan-pembatasan yang jelas dan tidak memberikan kebebasan mutlak pada pelaku pendidikan.

c. Metode Targhib

Targhib diartikan dengan kalimat yang melahirkan keinginan kuat (bahkan sampai pada tingkat rindu), membawa seorang tergerak untuk melakukan amalan. Targhib menjadi metode pendidikan yang memberi efek motivasi untuk beramal dan mempercayai sesuatu yang dijanjikan.

Semua targhib yang disampaikan Allah kepada manusia adalah bersifat janjijanji yang pasti akan nyata. Wujud janji tersebut ada yang dalam lingkup kehidupan dunia jangka pendek atau kehidupan jangka panjang, yaitu alam akhirat nanti.

\section{d. Metode Tarhib}

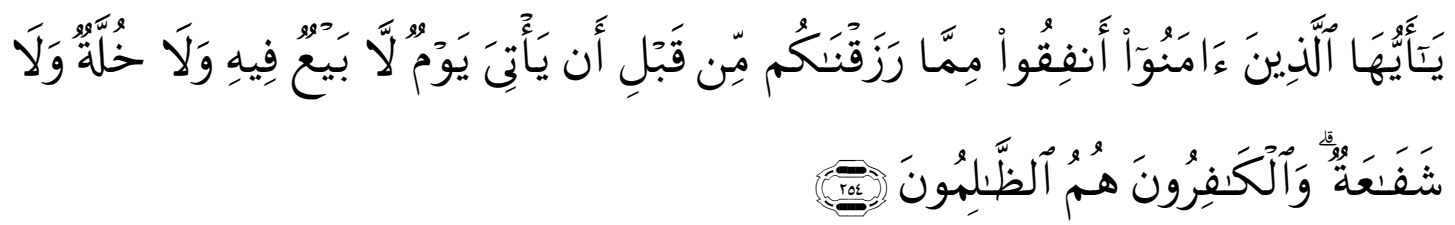

Terjemahnya:

Wahai orang-orang yang beriman! infakkanlah (di jalan Allah) sebagian dari rezki yang Telah kami berikan kepadamu sebelum datang hari yang pada hari itu tidak ada lagi jual beli dan tidak ada lagi syafa'at. dan orang-orang kafir Itulah orang-orang yang zalim' (Q.S. Al-Baqarah, [2]: 254). ${ }^{45}$

Dalam Al-Qur'an, tarhib adalah upaya menakut-nakuti manusia agar menjauhi dan meninggalkan suatu perbuatan. Landasan dasarnya adalah ancaman. Semua tarhib yang disampaikan Allah kepada manusia bersifat ancaman yang disampaikan dalam proses mendidik anak.

${ }^{45}$ Ibid., h. 52. 
Metode tarhib yang diungkapkan Al-Qur'an telah banyak mengubah diri manusia, dari yang berani berbuat dosa menjadi takut, dari berani berbuat zalim menjadi takut, dari berani berkhianat menjadi takut, dan begitu seterusnya.

e. Metode Pembiasaan

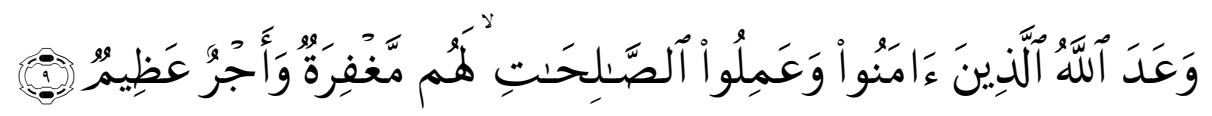

Terjemahnya:

Allah Telah menjanjikan kepada orang-orang yang beriman dan yang beramal saleh, (bahwa) untuk mereka ampunan dan pahala yang besar (Q.S. Al-Maa'idah, [5]: 9). ${ }^{46}$

Ayat di atas memberikan sebuah penghargaan yang amat istimewa kepada orang-orang beriman yang selalu melakukan kebaikan yaitu berupa ampunan dan pahala yang besar. Kebaikan atau pembiasaan amal kebaikan menjadi sikap dan profil manusia berkarakter.

Al-Qur'an menjadikan kebiasaan itu sebagai salah satu metode pendidikan. Lalu ia mengubah seluruh sifat-sifat baik menjadi kebiasaan, sehingga jiwa dapat menunaikan kebiasaan itu tanpa kehilangan banyak tenaga dan tanpa menemukan banyak kesulitan. Sebab dengan pembiasaan melakukan kebaikan inilah anak akan bertindak tanpa adanya bentuk paksaan dari lingkungannya

Menurut Abdul Majid, proses pembiasaan harus dimulai dan ditanamkan kepada anak sejak dini. Potensi keimanan manusia yang diberikan oleh Allah harus senantiasa dipupuk dan dipelihara dengan memberikan pelatihan-pelatihan dalam beribadah. Jika pembiasaan sudah ditanamkan, maka anak tidak akan merasa berat lagi untuk beribadah, bahkan ibadah akan menjadi bingkai amal dan sumber kenikmatan dalam hidupnya. ${ }^{47}$

${ }^{46}$ Ibid., h. 145.

${ }^{47}$ Abdul Majid, Pendidikan Karakter dalam Perspektif Islam, (Bandung: PT. Remaja Rosdakarya, 2012), h. 130. 
144 | MUSAWA, Vol. 11 No. 1 Juni 2019 : 123 - 150

Jadi, Metode pembiasaan ini mendorong dan memberikan ruang kepada anak didik pada teori-teori yang membutuhkan aplikasi langsung, sehingga teori yang berat dapat menjadi ringan bagi anak didik bila sering kali dilaksanakan.

f. Metode Keteladanan

Salah satu aspek terpenting dalam mewujudkan integrasi iman, ilmu, dan amal adalah dengan adanya figur utama yang menunjang hal tersebut. Dialah sang pendidik yang menjadi sentral pendidikan, sehingga dapat dikatakan bahwa keteladanan merupakan aspek penting terpenting dari proses pendidikan. Selain itu, fitrah manusia adalah suka mengikuti atau mencontoh, bahkan fitrah manusia adalah lebih kuat dipengaruhi dan melihat contoh dibandingkan dari hasil bacaan atau mendengar.

Abu Ishaq Jibniyati $(369$ H) mengatakan bahwa janganlah kamu titipkan pendidikan anak-anakmu kecuali pada orang yang baik agamanya, sesungguhnya corak keagamaan seorang anak tergantung pada gurunya. ${ }^{48}$

Contoh metode pendidikan keteladanan yang paling berhasil adalah pendidikan di masa Rasulullah SAW, dimana pendidikan yang langsung berpusat pada diri beliau dengan menampilkan keteladanan dalam segala aspek. Allah Swt berfirman dalam (Q.S. Al-Ahzab, [33]: 21), yaitu:

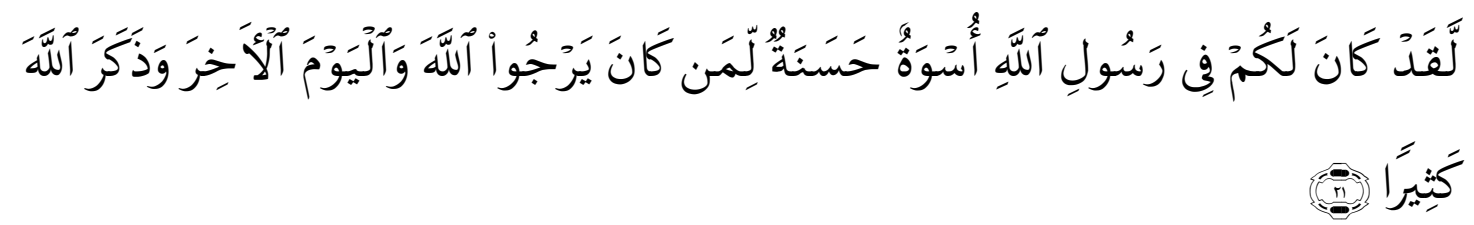

Terjemahnya:

Sesungguhnya Telah ada pada (diri) Rasulullah itu suri teladan yang baik bagimu (yaitu) bagi orang yang mengharap (rahmat) Allah dan (kedatangan) hari kiamat dan dia banyak menyebut Allah' (Q.S. Al-Ahzab, [33]: 21). ${ }^{49}$

\footnotetext{
${ }^{48} \mathrm{Abu}$ Umar bin Umar Diterjemahkan Oleh Ulil Amri Syafri, Falsafah at-Tarbiyah fi Al-Qur'an Al-karim, (Beirut: Dar Al-Maktabi 1420/2000), h. 218.

${ }^{49}$ Departemenen Agama Republik Indonesia, Al-Qur'an, h. 595.
} 


\section{Penerapan Pendidikan Karakter pada Anak Usia Dini di Sekolah}

Membina dan mendidik akhlak kepada anak didik, dalam arti untuk membentuk karakter baik, maka perlu dibina dan dilatih karakternya melalui pembiasaan mandiri, sopan santun, kreatif, rajin dan tanggung jawab. ${ }^{50}$ Karakter erat kaitannya dengan kekuatan moral, jadi orang yang berkarakter adalah orang yang mempunyai kualitas moral positif. Dengan demikian, pendidikan karakter, secara implisit mengandung arti membangun perilaku yang didasari dengan dimensi moral yang baik. Guru membantu membentuk watak anak didik. Kaitannya sikap dan perilaku budi pekerti, karakter yang utuh dan menyeluruh tidak sekedar membentuk anak-anak menjadi pribadi yang cerdas dan baik, melainkan juga bisa membiasakan dan menerapkan nilai-nilai karakter dalam kehidupan sehari-hari mereka.

Pendidikan karakter menurut Suyanto sebaiknya diterapkan sejak usia dini atau yang biasa disebut oleh ahli psikologi sebagai usia emas (golden age) ${ }^{51}$ Karena diusia ini terbukti sangat menentukan kemampuan anak dalam mengembangkan potensi dan bakatnya. Pendidikan yang berorientasi pada watak anak didik merupakan suatu hal yang tepat. Dalam perspektif pedagogik, lebih memandang bahwa pendidikan itu mengembangkan dan memfasilitasi watak, bukan membentuk watak. Jika watak dibentuk, maka tidak ada proses pendidikan.

Dari kesimpulan pemaparan Suyanto mengenai penanaman karakter dimulai sejak dini atau biasa disebut dengan masa golden age, ini merupakan hal yang sangat vital pada perkembangan psikis anak. Karena di masa golden age tersebut, seorang anak masih minim pengaruh dari luar. Anak biasanya terbiasa cenderung lebih kepada hal meniru apa yang ia lihat. Disinilah yang menentukan pembentukan

\footnotetext{
${ }^{50}$ Suyanto, Model Pembinaan Pendidikan Karakter di Lingkungan Sekolah, (Jakarta: Direktorat Jendral Manajemen Dasar dan Menengah Kementrian Pendidikan Nasional, 2010), h. 54

${ }^{51}$ Syamsul Kurniawan, Pendidikan Karakter: Konsepsi \& Implementasinya Secara Terpadu di Lingkungan Keluarga, Sekolah, Perguruan Tinggi \& Masyarakat, (Yogjakarta: Ar-ruzz Media,2014), h. 33
} 
146 | MUSAWA, Vol. 11 No. 1 Juni 2019 : 123 - 150

pribadi anak tersebut. Oleh karena nya, penanaman hal-hal positif terkait pendidikan karakter sangat efektif diterapkan sejak anak diusia dini.

Pada hakikatnya anak usia dini memiliki karakteristik yang berbeda bila dibandingkan dengan orang dewasa. Anak usia dini memiliki rasa ingin tahu yang cukup tinggi, suka bermain, meniru dan berimajinasi tentu karakteritik iniah yang akan dijadikan pijakan dalam menanamkan nilai-nilai karakter pada anak usia dini tersebut.

Penanaman karakter dilaksanakan secara tidak langsung melalui proses belajar mengajar di dalam kelas dan bersifat non-tematis. Jadi, setiap guru bisa kreatif memberikan pencerahan tentang pendidikan nilai terhadap anak didik melalui materi mata pelajaran yang sedang diajarkannya. penanaman karakter dimasukkan atau diinfuskan dalam seluruh materi pelajaran yang diajarkan. Guru bertanggung jawab menemukan dimensi moral dari mata pelajaran yang diajarkannya sehingga anak didik tidak kehilangan waktu dalam mempelajari materi, namun juga tidak kehilangan kesempatan untuk memperoleh inspiraasi nilai-nilai hidup dari mata pelajaran yang sedang dipelajarinya. ${ }^{52}$

Penanaman karakter di lingkungan sekolah bertujuan untuk meningkatkan mutu penyelenggaraan dan hasil pendidikan di sekolah yang mengarah pada pencapaian pembentukan karakter dan akhlak mulia anak didik secara utuh, terpadu, dan seimbang sesuai standar kompetensi lulusan. Melalui pendidikan karakter diharapkan anak didik mampu secara mandiri meningkatkan dan menggunakan pengetahuannya, mengkaji dan menginternalisasi. serta mempersonalisasi nilai- nilai karakter dan akhlak mulia sehingga terwujud dalam perilaku sehari-hari. ${ }^{53}$

Terkait hal ini, maka Peran guru dalam membentuk karakter anak didik yaitu dengan membiasakan menerapkan karakter pada diri anak didik secara berkelanjutan sehingga akan menjadi kebiasaan dan melekat pada diri anak didik tersebut.

${ }^{52}$ Doni Koesoema A., Pendidikan Karakter Utuh dan Menyeluruh, (Yogyakarta: PT KANISIUS, 2012), h. 18

${ }^{53}$ Syamsul Kurniawan, Pendidikan, h. 127 
Penanaman karakter di sekolah mengarah pada peningkatkan pencapaian pembentukan karakter dan akhlak mulia anak didik secara utuh, terpadu dan seimbang sesuai standar kompetensi lulusan. Karakter dapat diintregasikan dalam pembelajaran pada setiap mata pelajaran. Oleh karena itu pembentukan karakter dapat dikembangakan melalui kegiatan rutin, kegiatan spontan, keteladanan, dan pengkodisian, Kaitannya dengan pendidikan karakter dalam pembelajaran.

Bentuk pelaksanaan pendidikan pada Anak Usia Dini dapat dilakukan dengan cara bermain melalui sentra. Sentra-sentra yang tersedia, yaitu sentra balok, sentra main peran, sentra Qur'an, sentra persiapan dan entra keterampilan

Sentra balok, yaitu sentra yang dirancang khusus untuk menstimulasi kecerdasan logika matematika, bahasa, kerja sama, dan juga dapat memecahkan berbagai masalah saat menuangkan ide atau gagasan anak dalam bentuk bangunan. Misalnya anak diberi tugas merancang suatu bangunan, contohnya: membangun kebun binatang, istana, rumah sakit, dll. Sentra main peran, yaitu sentra yang memfasilitasi anak didik untuk dapat mengembangkan kemampuan bahasa, kognitif, sosial, dan emosi anak dengan memberikan banyak kesempatan untuk memainkan peran menjadi tokoh-tokoh dokter, koki, guru, pengusaha, polisi, dll. Sentra Qur'an, yaitu sentra yang dirancang untuk mengembangkan kemampuan anak dalam mengenal huruf-huruf hijaiyah, mengaji, shalat, dan berwudhu. Sentra persiapan, yaitu pusat kegiatan bermain untuk mempersiapkan anak mengenal tulisan, huruf, dan menghitung. Kegiatan ini berguna untuk membantu anak mempersiapkan diri memasuki sekolah dasar. Sentra keterampilan memberikan kesempatan pada anak untuk mengembangkan keterampilannya terutama keterampilan tangan dengan menggunakan berbagai bahan dan alat, seperti: melipat, menggunting, mewarnai, dan prakarya dengan menggunakan adonan, di sentra ini anak bermain sambil belajar mengasah rasa keindahan, membangun kemandirian, kerja sama, tanggung jawab, melatih koordinasi mata, tangan, dan pikiran.

Tiap-tiap sentra mempunyai tujuan masing-masing sesuai dengan pengembangannya. Namun, pada intinya tiap sentra mempunyai satu tujuan pokok 
148 | MUSAWA, Vol. 11 No. 1 Juni 2019 : 123 - 150

yaitu mengoptimalkan potensi anak dalam kemampuan kognitif, afektif, dan psikomotorik, serta menanamkan nilai-nilai agama pada anak.

kegiatan sentra sengaja dibuat berdasarkan kebutuhan anak untuk mengamati setiap perkembangan anak. Jadi, kegiatan sentra adalah pengelolaan kelas yang terpusat pada satu kegiatan pembelajaran secara khusus untuk mengembangkan berbagai aspek perkembangan, dan memberikan semangat kepada anak dalam proses pembelajaran.

\section{PENUTUP}

Berdasarkan uraian di atas, dapat disimpulkan bahwa:

1. Pendidikan Karakter Pada Anak Usia Dini merupakan hal yang mutlak diberikan dengan tujuan untuk mengembangkan potensi dasar anak agar ia tumbuh menjadi sosok yang berhati baik, berpikiran baik dan berperilaku baik

2. Implementasi pendidikan karakter di sekolah pada anak usia dini dapat dilakukan melalui pembelajaran berbasis sentra yaitu sentra balok, sentra main peran, sentra Qur'an, sentra persiapan dan sentra keterampilan. Ketiga sentra tersebut saling keterkaitan antara satu dengan yang lainnya yang akan menjadikan anak didik memiliki karakter sesuai dengan nilai-nilai Islami

\section{DAFTAR PUSTAKA}

Al-Bukhori, Shohihul Bukhori, Jilid II. Singapura: Sulaman Mar’i, t.th.

Al-Ghazali, Mengobati Penyakit Hati Membentuk Akhlak Mulia, Bandung: Kharisma,1994.

Aman, Saifuddin. 8 Pesan Lukman Al-Hakim, Jakarta: Almawardi Prima, 2008.

Departemenen Agama Republik Indonesia, Al-Qur'an dan Terjemahnya. Surabaya: Duta Ilmu, 2002.

Depdiknas, Kurikulum Hasil Belajar Pendidikan Anak Usia Dini, Jakarta: Depdiknas, 2002. 
Fadlillah, Muhammad \& Khorida, Lilif Mualifatu. Pendidikan Karakter Anak Usia Dini, Jogjakarta: Ar-Ruzz Media, 2013.

Hasan, Maimunah, PAUD (Pendidikan Anak Usia Dini), Yogyakarta: DIVA Press, 2010.

Hermowo, Self Digesting : Alat Menjelajahi dan Mengurai Diri, Bandung: Mizan Media Utama, 2004.

Ihsan, Fuad. Dasar-Dasar Kependidikan, Jakarta: Rineka Cipta, 2008.

Koesoema A., Doni. Pendidikan Karakter Utuh dan Menyeluruh, Yogyakarta: PT KANISIUS, 2012.

Kurniawan, Syamsul. Pendidikan Karakter: Konsepsi \& Implementasinya Secara Terpadu di Lingkungan Keluarga, Sekolah, Perguruan Tinggi \& Masyarakat, Yogjakarta: Ar-ruzz Media, 2014.

Majid, Abdul. Andayani, Dian. Pendidikan Karakter Perspektif Islam, Bandung: PT. Remaja Rosdakarya, 2012.

Moeslichatoen R, Metode Pengajaran di Taman Kanak-Kanak, (Cet. I; Jakarta: Rosda Karya, 2007.

Munir, Abdullah. Pendidikan Karakter, Yogyakarta: Pedagogia, 2010.

Muqtadir, Ibrahim Abdul. Wisdom Of Luqman El-hakim: 12 cara membentengi Kerusakan Akhlak, Solo:Aqwam, 2008.

Nata, Abuddin. Kapita Selekta Pendidikan Islam, Jakarta: PT. Raja Grafindo Persada, 2012.

Patmonodewo, Soemarti. Pendidikan anak Pra Sekolah. Jakarta: PT Asdi Mahastya, 2003.

Republik Indonesia, Undang-Undang Perlindungan Anak (UU RI No. 23 Tahun 2002), Jakarta: Sinar Grafika, 2009.

Samani, Muchlas dan Hariyanto, Konsep dan Model Pendidikan Karakter, Bandung: PT Remaja Rosdakarya, 2012. 
150 | MUSAWA, Vol. 11 No. 1 Juni 2019 : 123 - 150

Shihab, M. Quraish, Tafsir Al-misbah, Pesan, Kesan dan Keserasian Al-Qur'an, Jakarta: Lentera Hati, 2002.

Sukmadinata, Nana Syaodih. Landasan Psikologi Proses Pendidikan, Cet.II; Bandung: Remaja Rosdakarya, 2004.

Suyanto, Model Pembinaan Pendidikan Karakter di Lingkungan Sekolah, Jakarta: Direktorat Jendral Manajemen Dasar dan Menengah Kementrian Pendidikan Nasional, 2010.

Syafri, Ulil Amri, Pendidikan Karakter Berbasis Al-Qur'an, cet. I; Jakarta: PT. Raja Grafindo Persada, 2012.

Tafsir, Ahmad. Pendidikan Agama Islam, Bandung: Maestro, 2008.

Uhbiyati, Nur. Ilmu Pendidikan Islam, Bandung: Pustaka Setia, 1989.

Undang-Undang, Undang-Undang RI Nomor 20 tahun 2003 tentang Sistem Pendidikan Nasional, Bandung: Citra Umbara, 2006.

Wiyani, Novan Ardy. Manajemen Pendidikan Karakter : Konsep dan Implementasinya di Sekolah, Yogyakarta: Pedagogia, 2012. 